\title{
Embryology of the Eye and Its Adnexa
}




\section{Y. Robert Barishak}

\section{Embryology of the Eye and Its Adnexa}

2nd, revised edition

80 figures and 1 table, 2001

KARGER $\begin{aligned} & \text { Basel· Freiburg } \cdot \text { Paris } \cdot \text { London } \cdot \text { New York } \cdot \\ & \text { New Delhi } \cdot \text { Bangkok } \cdot \text { Singapore } \cdot \text { Tokyo } \cdot \text { Sydney }\end{aligned}$ 


\section{Y. Robert Barishak}

Aaronson Street No. 55

Ramat Gan, 52293 Israel

\section{The first edition appeared in the book series Developments in Ophthalmology Vol. 34, 'Embryology of the Eye and its Adnexa'}

Library of Congress Cataloging-in-Publication Data

Barishak, Y. Robert.

Embryology of the eye and its adnexa/Y. Robert Barishak.--2nd ref. ed.

p. cm.

"The first edition appeared in the book series Development in opthalmology Vol. 34, Embryology of the eye and its adnexa."

Includes bibliographical references and index.

ISBN 3805571798 (hardcover)

1. Eye--Growth. 2. Embryology, Human. 3. Adnexa oculi--Growth. I. Title

QP475.B345 2001

612.6'40184--dc21

2001018983

Drug Dosage. The authors and the publisher have exerted every effort to ensure that drug selection and dosage set forth in this text are in accord with current recommendations and practice at the time of publication. However, in view of ongoing research, changes in government regulations, and the constant flow of information relating to drug therapy and drug reactions, the reader is urged to check the packages insert for each drug for any change in indications and dosage and for added warnings and precautions. This is particularly important when the recommended agent is a new and/or infrequently employed drug.

All rights reserved. No part of this publication may be translated into other languages, reproduced or utilized in any form or by any means electronic or mechanical, including photocopying, recording, microcopying, or by any information storage and retrieval system, without permission in writing from the publisher.

(C) Copyright 2001 by S. Karger AG, P.O. Box, CH-4009 Basel (Switzerland)

www.karger.com

Printed in Switzerland on acid-free paper by Reinhardt Druck, Basel

ISSN 0250-3751

ISBN 3-8055-7179-8 
This book is dedicated to my wife Rachel

for her life-long support 


\section{Contents}

\begin{aligned} 1 & Introduction \\ \hline 3 & Embryogenesis \\ \hline 7 & Organogenesis \\ \hline 7 & Fourth Week \\ 10 & Fifth Week \\ 15 & Sixth Week \\ 20 & Seventh Week \\ 27 & Eighth Week \\ & \\ 38 & Differentiation \\ \hline 38 & Third Month \\ 52 & Fourth Month \\ 67 & Fifth Month \\ 76 & Sixth Month \\ 86 & Seventh Month \\ 98 & Eighth Month \\ 99 & Ninth Month \\ & \\ 104 & Birth and after Birth \\ \hline & \\ 118 & References \\ \hline & \\ 129 & Subject Index \\ \hline & \end{aligned}

